Sains Malaysiana 49(12)(2020): 2901-2912

http://dx.doi.org/10.17576/jsm-2020-4912-03

\title{
Rapid Manipulation of Extracellular Vesicles using Dielectrophoretic Mechanism
}

(Manipulasi Pantas Vesikel Ekstrasel menggunakan Mekanisme Dielektroforesis)

\author{
Nur mas Ayu Jamaludin, Muhammad Khairulanwar Abdul Rahim, Azrul Azlan Hamzah, Nadiah \\ ABU, MUHAMAD RAMDZAN BUYONG*
}

\begin{abstract}
Extracellular vesicles (EVs) are small entities that are released by most cell types. EVs are important form of intercellular communication and a rich source of biomarkers for a wide variety of diseases. Many methods for EVS isolation have been utilized, however, most of them have significant drawbacks including lengthy processing time, high cost, shortfalls in selectivity and surface marker dependency. In consideration of these issues, this paper discussed on the dielectrophoresis (DEP) microelectrode method designed to rapidly isolate EVs from its medium. The advantage of this DEP microelectrode is the capability of isolating EVS using a droplet of $1 \mu \mathrm{L}$ placed onto the microelectrode within $30 \mathrm{~s}$ and $20 \mathrm{~V}$ peak-to-peak $\left(V_{p-p}\right)$ of alternating current $(A C)$. The method used in the characterization of sample are dynamic light scattering (DLS) and transmission electron microscopy (TEM); both prove the heterogeneity of EVs ' population and the EVs appear to be spherical with size ranging from 40 to $200 \mathrm{~nm}$. The experimental results from this preliminary experiment show that the DEP microelectrode was able to manipulate EVS as evidenced by the negative dielectrophoresis (NDEP) fluorescent images. Further investigation of grid analysis conducted shows the consistency of the theory and the results presented. Corrected Total Cell Fluorescence (CTCF) values from the grid analysis concluded that the EVS were manipulated to the center of region of interest, (ROI). Therefore, this DEP technique suggests a rapid strategy for EVs isolation from its medium in small quantity while maintaining accuracy and cost-effectivity.
\end{abstract}

Keywords: Dielectrophoresis; extracellular vesicles; isolation; manipulation; particle separation

ABSTRAK

Vesikel ekstrasel (EV) adalah entiti kecil yang dilepaskan oleh kebanyakan jenis sel. EV adalah bentuk komunikasi antara sel yang penting dan merupakan sumber biopenanda yang kaya untuk pelbagai jenis penyakit. Banyak kaedah untuk pengasingan EV telah digunakan, namun, kebanyakan daripada mereka mempunyai kekurangan yang signifikan termasuk waktu pemprosesan yang panjang, kos yang tinggi, kekurangan pilihan dan kebergantungan penanda permukaan. Berdasarkan permasalahan ini, kajian ini membincangkan kaedah dielektroforesis (DEP) mikroelektrod yang dirancang untuk mengasingkan EV dengan cepat daripada mediumnya. Kelebihan mikroelektrod DEP ini adalah kemampuannya mengasingkan EV menggunakan titisan 1 LL yang diletakkan ke atas mikroelektrod dalam masa 30 saat dan voltan arus ulang alik (AC) yang menggunakan 20 volt puncak-ke-puncak $\left(V_{p-p}\right)$. Kaedah yang digunakan dalam pencirian sampel adalah penyerakan cahaya dinamik (DLS) dan mikroskop elektron transmisi (TEM); keduaduanya membuktikan keheterogenan populasi EV dan EV kelihatan bulat dengan ukuran antara $40 \mathrm{~nm}$ hingga 200 nm. Hasil daripada uji kaji awal menunjukkan bahawa mikroelektrod DEP dapat memanipulasi EV seperti yang dibuktikan oleh imej pendarfluor negatif dielektrophoresis (NDEP). Kajian lebih lanjut mengenai analisis grid yang dijalankan menunjukkan ketekalan teori dan hasil yang dikemukakan. Nilai Jumlah Pendarflour Sel Betul (CTCF) daripada analisis grid menyimpulkan bahawa EV dimanipulasi ke pusat rantau tumpuan (ROI). Oleh itu, teknik DEP ini mencadangkan strategi cepat untuk pengasingan EV daripada mediumnya dalam jumlah yang sedikit di samping mengekalkan ketepatan dan keberkesanan kos.

Kata kunci: Dieletroforesis; manipulasi; pemisahan zarah; pengasingan; vesikel ekstrasel

\section{INTRODUCTION}

Extracellular vesicles (EVs) have become an important discovery as they create a gateway to the knowledge in various capacities in physiology and pathology. Research on EVs can unlock the mechanism of intercellular communication and transmission of macromolecules. The study of EVs can also further our understanding on the development of diseases as well as in the transmission of protein, lipids, mRNA, miRNA, and DNA. Additionally, due 
to the properties of EVs, that are made of cell membranes, they have higher tolerance by the host as compared to synthetic polymers which makes them useful vectors for medical drugs (Edgar 2016).

In the physiological and pathological context, EVs are able to support several biological functions. Firstly, EVs can remove misfolded proteins and superfluous molecular material from the cell (Pegtel et al. 2014). Secondly, EVs can also transfer specific types of biomolecules between cells locally or through a distance using certain mediums such as blood (Haqqani et al. 2013). This particular property of EVs is what makes it a huge potential for medical research. EVs do not only serve the important role of cell to cell to communication but also in physiological process, such as tissue repair, cell maintenance, and processing immune system which can be essential in fighting diseases, in this case, cancer (Tetta et al. 2013).

The population of EVs is heterogeneous, and several subtypes can be found. The subtypes include, exosomes, and microvesicles which are distinguished by their size and biogenesis mechanisms (Muralidharan-Chari et al. 2009). The most studied EVs is the exosome which consists of a homogeneous cell of spherical vesicles that sized from 30 to $100 \mathrm{~nm}$ in diameter (Raposo \& Stoorvogel 2013). Microvesicles are large vesicles sizing from 100 to $1000 \mathrm{~nm}$ in diameter (Doyle \& Wang 2019). They are formed through the plasma membrane of the cells by direct outward budding and shedding (Van Niel et al. 2018). Cells release heterogeneous vesicles of diverse sizes and intracellular origins. These entities can be isolated from multiple types of bodily fluids, such as blood, urine, saliva, breast milk, amniotic fluid, semen, cerebrospinal, and synovial fluids (Admyre et al. 2007; Caby et al. 2005; Dixon et al. 2018; Pisitkun et al. 2004; Vojtech et al. 2014; Zlotogorski-Hurvitz et al. 2015).

Due to their special attribute to serve as a 'carrier' that can move and exchange molecules, EVs have been studied extensively for the purpose of cell to cell communication. EVs are able to access certain challenging areas in the organism such as the brain and represents a potential clinical biomarker to provide information on the pathophysiology of several diseases. However, the obvious barrier is the lack of standardized and sensitive methods and technologies for the isolation, enrichment and detection from biological fluids. Using current technology, EVs will be isolated based on their amount, type and purity of the obtained EV. Each isolation method has advantages and disadvantages and the selection of methods are also based on the different type of factors, such as starting material, volume, desired grade of purity, and isolation purpose. Despite having the prospect to have value for further research in faster diagnostic, some limitations come with the purification and characterization, also, to be challenging in the technical area.

The main interest of researchers in recent times has been in the field of distinguishing the properties between a healthy and unhealthy cell. A technique, for this reason, is utilized, called the dielectrophoresis (DEP) (Rahman et al. 2017). DEP is the movement of particles by a trapping force in a non-uniform electric field when the particles and surrounding medium have different polarizabilities. The polarization of the charged or neutral particles is induced by an electric field generated from alternating current (AC) or direct current (DC) potentials. The polarized particles would array in various motions, including attraction or repulsion from the electrode by changing the frequency of the applied electric field, and this motion is in response to positive DEP (PDEP) or negative DEP(NDEP), respectively. One of its applications is in the medical field.

DEP is a more accurate, quick, and low-cost technique that are able to manipulate the EVs to screen diseases such as cancer cells. Since DEP technique can differentiate cells by manipulating cell dielectric properties, this can potentially be explored in the case of EVs (Gascoyne \& Shim 2014). This study suggests for a rapid manipulation towards EVs, the ability of this technique to manipulate EVs within a minute. DEP has emerged as an important technique for the manipulation of micro- and nano-sized particles in recent years. The focus on dielectrophoresis as a useful technique for the manipulation of particles where it was used for the extensive manipulation of living cells and DNA.

\section{DIELECTROPHORESIS THEORY}

DEP has been widely researched in various fields and is defined as the motion of neutral particles due to the application of an external non-uniform electric field. The motion occurs due to the polarization of neutral particles, which then experience a force called the dielectrophoretic (DEP) force (Kadaksham et al. 2004). The response when it moves towards the electrode is called PDEP, while the response when it moves away is called NDEP as shown in Figure 1.

The difference between dielectrophoresis and electrophoresis is that electrophoresis is a force in a uniform field where the movement of the particles is depending on the charge. If the particles are positively charged (also called cataphoresis) the movement will incline towards the negative electrode, and if the particles are negatively charged (also called anaphoresis the movement will incline towards the positive electrode (Rahman et al. 2017). 


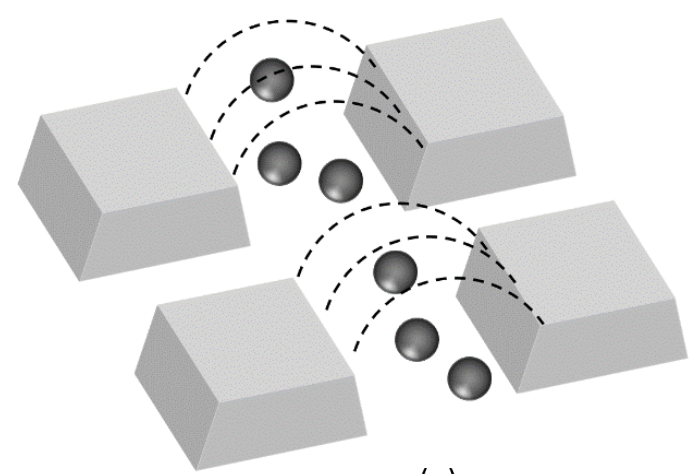

(a)

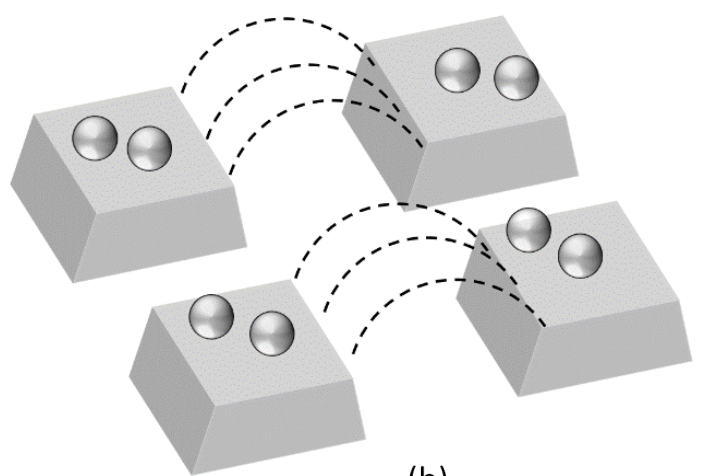

(b)

FIGURE 1. (a) Negative DEP, NDEP (b) Positive DEP, PDEP

The unique property of DEP is that the particles can be manipulated by subjecting them to different frequencies. Another important property that makes DEP very important and useful in many fields and applications is that the particles can position themselves in a stable position using electromagnetic fields compared to electrophoresis. Electrophoresis on the other hand, cannot create a stable position due to its property of being charged. Both of the phenomena of PDEP and NDEP depends on the Clausius-Mossotti Factor (Shafiee et al. 2013):

$$
\mathrm{F}_{\mathrm{DEP}}=2 \pi \varepsilon_{\mathrm{m}} \mathrm{r}^{3} \operatorname{Re}\left(\mathrm{F}_{\mathrm{CM}}\right) \nabla\left|\mathrm{E}^{2}\right|
$$

where $\varepsilon_{\mathrm{m}}$ is the medium permittivity; $\mathrm{r}$ is the particle radius; and $\operatorname{Re}\left(\mathrm{F}_{\mathrm{CM}}\right)$ is the real part of Clausius-Mossotti factor of the particle; and $\nabla\left|\mathrm{E}^{2}\right|$ defines the gradient of the external field magnitude square. $\mathrm{F}_{\mathrm{CM}}$ is the Clausius-Mossotti factor of the particle in a medium and for a spherical particle, it is defined as:

$$
\mathrm{F}_{\mathrm{CM}}=\frac{\varepsilon_{\mathrm{p}}^{*}-\varepsilon_{\mathrm{m}}^{*}}{\varepsilon_{\mathrm{p}}^{*}+2 \varepsilon_{\mathrm{m}}^{*}}
$$

where $\varepsilon_{\mathrm{p}}{ }^{*}$ and $\varepsilon_{\mathrm{m}}{ }^{*}$ are the complex permittivity of the particle and medium, respectively, (3):

$$
\begin{gathered}
\varepsilon_{\mathrm{p}}^{*}=\varepsilon_{\mathrm{p}}-\mathrm{j} \frac{\sigma_{\mathrm{p}}}{\omega} \\
\varepsilon_{\mathrm{m}}^{*}=\varepsilon_{\mathrm{m}}-\mathrm{j} \frac{\sigma_{\mathrm{m}}}{\omega}
\end{gathered}
$$

In (3) and (4), $\varepsilon_{\mathrm{p}}$ and $\varepsilon_{\mathrm{m}}$ denote the electrical permittivity and conductivity, respectively, $\mathrm{j}$ is $\sqrt{-1}$ and $\omega$ is the angular frequency of the applied signal.

For low frequency electric fields, the sign of the Clausius-Mossotti factor is determined by the electrical conductivities of the particle and the medium, (5), whereas it depends on the permittivity values at high frequencies, (4b):

$$
\begin{aligned}
& \lim _{\omega \rightarrow 0} \operatorname{Re}\left(\mathrm{f}_{\mathrm{CM}}\right)=\frac{\sigma_{\mathrm{p}}-\sigma_{\mathrm{m}}}{\sigma_{\mathrm{p}}+2 \sigma_{\mathrm{m}}} \\
& \lim _{\omega \rightarrow 0} \operatorname{Re}\left(\mathrm{f}_{\mathrm{CM}}\right)=\frac{\varepsilon_{\mathrm{p}}-\varepsilon_{\mathrm{m}}}{\varepsilon_{\mathrm{p}}+2 \varepsilon_{\mathrm{m}}}
\end{aligned}
$$

Equation 5 indicates that, for very low field frequencies; if $\sigma_{p}$ is much larger than $\sigma_{m}$; the maximum value of the $\mathrm{F}_{\mathrm{CM}}(1.0)$ occurs. In contrast, if $\sigma_{\mathrm{m}}$ is much larger than $\sigma_{\mathrm{p}}$; then the $\mathrm{F}_{\mathrm{CM}}$ will be at its minimum value $(-0.5)$. These outcomes are also valid for high field frequencies when permittivities are concerned (6).

If $\varepsilon_{\mathrm{p}}{ }^{*}>\varepsilon_{\mathrm{m}}{ }^{*}$, particle is pulled toward higher electric field density region, observing PDEP force. If $\varepsilon_{\mathrm{p}}{ }^{*}<\varepsilon_{\mathrm{m}}{ }^{*}$, particle is pushed toward low electric field density region, observing NDEP force. In addition, (2) shows that there is a frequency at which the $\operatorname{Re}\left(\mathrm{F}_{\mathrm{CM}}\right)$ becomes zero. This frequency is called as DEP crossover frequency $\left(\mathrm{f}_{\text {cross }}\right)$, which can be formulated for spherical particles as:

$$
\mathrm{f}_{\text {cross }}=\frac{1}{2 \pi} \sqrt{\frac{\left(\sigma_{\mathrm{m}}-\sigma_{\mathrm{p}}\right)\left(\sigma_{\mathrm{p}}+2 \sigma_{\mathrm{m}}\right)}{\left(\varepsilon_{\mathrm{m}}-\varepsilon_{\mathrm{p}}\right)\left(\varepsilon_{\mathrm{p}}+2 \varepsilon_{\mathrm{m}}\right)}}
$$

If two particles with similar sizes have different $\mathrm{f}_{\text {cross }}$, dielectric property-based separation can be achieved with DEP. If $f_{\text {cross }}$ values of particles are too close, these values can be separated by size-based DEP since DEP force is directly proportional to the cube of the particle radius (7). By varying the signal frequency, the DEP fingerprints can be determined, that is, the dielectric characteristics, of a particle in a medium. Once DEP fingerprints are determined, particles can be manipulated with DEP. 


\section{MATERIALS AND METHODS}

SOFTWARE MODELLING

Analytical modelling polarization factors for EVs (unique identifications of EVs) using MATLAB software. This method has been presented in several studies which involves bacteria, cancer cells, and red blood cells (Jamaludin et al. 2018; Rahim et al. 2018; Yunus et al. 2018).

The properties of physiological state of EVs will be calculated, which is divided into two, permittivity and conductivity value. From the permittivity and conductivity values, it can define the crossover frequency for EVs.

\section{CHARACTERIZATION OF EXTRACELLULAR VESICLES}

In this work, there are two characterization were being conducted which are transmission electron microscopy TEM) and dynamic light scattering (DLS). The first technique used in this study is TEM. This technique provides a great tool to process the size and morphology of EVs, to check the purity of the EVs, and to identify the protein in the EVs (Clayton et al. 2001). Next, DLS has been used in this work because of its ability to perform the particle size measurement within one or two minutes. DLS has the principle of Brownian motion of particles and correlates motion with the size of particles.

\section{TRANSMISSION ELECTRON MICROSCOPY (TEM)}

The EVs sample was analyzed using a transmission electron microscope (Fei Tecnai G2 Spirit Biotwin) using an accelerating voltage of $120 \mathrm{kV}$. Briefly, the EVs sample underwent staining method, the sample was dropped on the Formvar grid and stained with 3\% uranyl acetate for five minutes. Next, the sample was washed three times with distilled water. The sample was left to be dried on the grid before viewing on the transmission electron microscope.

\section{DYNAMIC LIGHT SCATTERING (DLS)}

DLS is a technique that depends on the scattering of a laser beam; also known as photon correlation spectroscopy. The DLS method's greatest advantage is its ability to measure the particle size. This optical technique is broadly utilized to measure and count extracellular vesicles (EV) by a monochromatic and coherent laser beam passes through a suspension of particles. The mechanism of DLS happens when a particle passes through the laser beam, the laser light is dispersed and scattered in all directions hence, by recording the intensity of the scattered light as a function of time, and the fluctuations can be observed due to Brownian motion of suspended particles.

The EVs sample was diluted with a ratio of 1:300 which represents the ratio of sample to the medium used, in this work, deionized water (DI water). The data were collected using cuvette with a dip cell and suspended in a $1500 \mu \mathrm{L}$ of water to be used with Zetasizer Nano ZS apparatus (Malvern Instruments, Malvern, UK) which equipped with $633 \mathrm{~nm} \mathrm{He-Ne} \mathrm{laser} \mathrm{and} \mathrm{its} \mathrm{operating} \mathrm{angle}$ of $173^{\circ}$.

\section{PREPARATION OF EXTRACELLULAR VESICLES WITH PKH26 LABELLING}

EVs used in this study was provided by one of the authors from UKM Medical Molecular Biology Institute (UMBI). The EVs were obtained via precipitation-based methods from cell culture medium of SW480 cells. The procedures can be seen in Figure 2. EVs were fluorescently labeled to monitor EV internalization using PKH26 (MINI26-1KT),
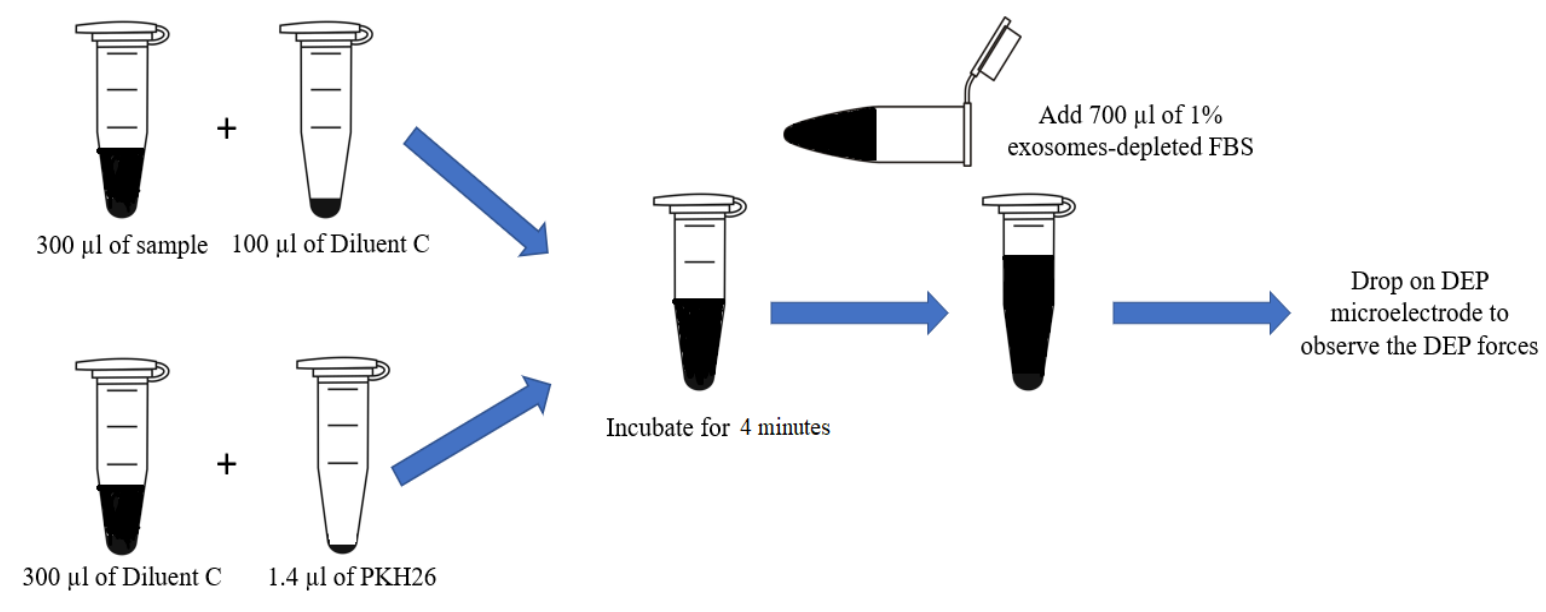

Incubate for 4 minutes

FIGURE 2. Procedures of staining by using PKH26 
a red membrane dye (Sigma-Aldrich, St. Louis, MO, USA), with minor modifications in accordance with the manufacturer's recommended protocol. In brief, 300 $\mu \mathrm{L}$ of exosomes was suspended in $100 \mu \mathrm{L}$ of Diluent C. Diluent $\mathrm{C}$ was combined with $1.4 \mu \mathrm{L}$ of PKH26 separately. The exosome solution was immediately mixed. The exosome solution was then combined with a stain solution and incubated for $4 \mathrm{~min}$. The labeling reaction was stopped by adding 1\% Fetal Bovine Serum (FBS) with an equal volume of $700 \mathrm{uL}$ (Sakha et al. 2016). The stained EVs were then observed under a fluorescent microscope (Olympus, BX53; Melville, NY, USA) to validate the procedure.

\section{EXPERIMENTAL SETUP FOR TESTING}

The microelectrode used with a tapered profile of $70^{\circ}$ as shown in Figure 4(a) was used to carry out this investigation towards EVs. EVs as the subjected particles that were stained previously using PKH26 needed to be viewed under a fluorescent microscope, hence, the experimental setup for this work was made under the fluorescent microscope (BA400; Motic, Wetzlar, Germany) with $40 \times$ magnification to see the reaction of the dielectrophoretic force, FDEP. The fluorescent microscope was equipped with a Dinoeye Eyepiece microscope camera (Dino-lite, Torrance, CA) to record

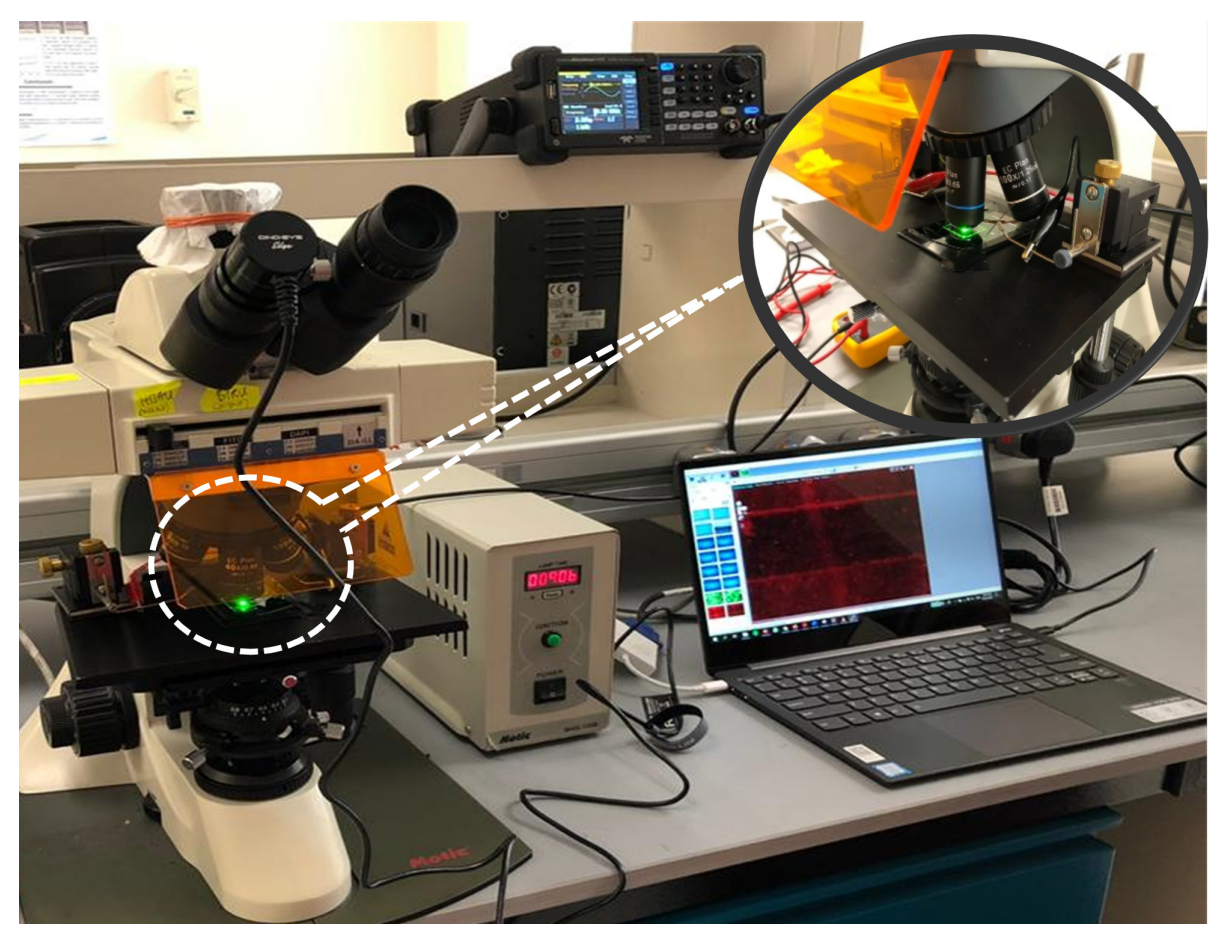

FIGURE 3. Experimental setup for DEP experimental work

the images and videos of the reaction. The microscope needs to be set to the correct wavelength in order to view the stained EVs. $1 \mu \mathrm{L}$ of stained EVs was dropped on the microelectrode and covered by a $1 \mathrm{~mm}$ glass slide to reduce the number of layers for ease of viewing purposes and to be able to see the FDEP reaction on the region of interest, ROI. The microscope needs to be adjusted according to the ROI. A sinusoidal alternating current (AC) was supplied by a function generator through the prober onto the microelectrode pad. Input frequency ranging from 100 $\mathrm{kHz}$ to $10 \mathrm{Mhz}$ was used in order to see both reactions of FDEP, which are PDEP and NDEP. $20 \mathrm{~V}$ peak-to-peak $\left(\mathrm{V}_{\mathrm{p}-\mathrm{p}}\right)$ was chosen because of Brownian motion towards EVs. This setup can be observed in Figure 3.
The graphics in Figure 4 shows the mechanism of FDEP manipulation towards EVs. EVs which consists of two distinct populations, exosomes (30-150 nm) and microvesicles (150-1000 nm), can be manipulated and separated using the concept of PDEP and NDEP. Figure 4(a) shows the ROI, the tapered microelectrode and the direction axes of particles (Buyong et al. 2017, 2015). In Figure 4(b), the EVs; exosomes and microvesicles are scattered before any supply is connected to the DEP microelectrode. Next, the EVs will be manipulated and then separated according to the input frequency supplied as illustrated in Figure 4(c). Finally, both exosomes and microvesicles were separated, exosomes were in PDEP region and microvesicles were in NDEP region as shown in Figure 4(d). 


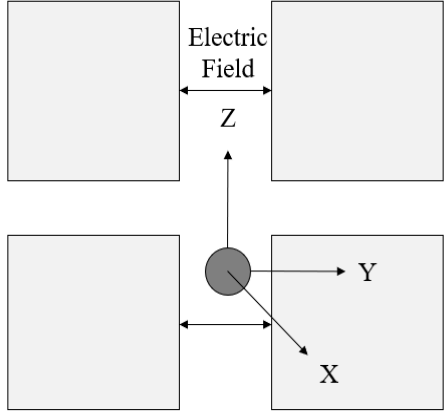

Plan View

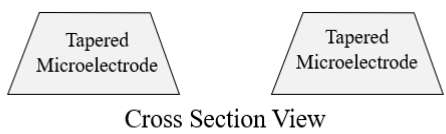

(a)
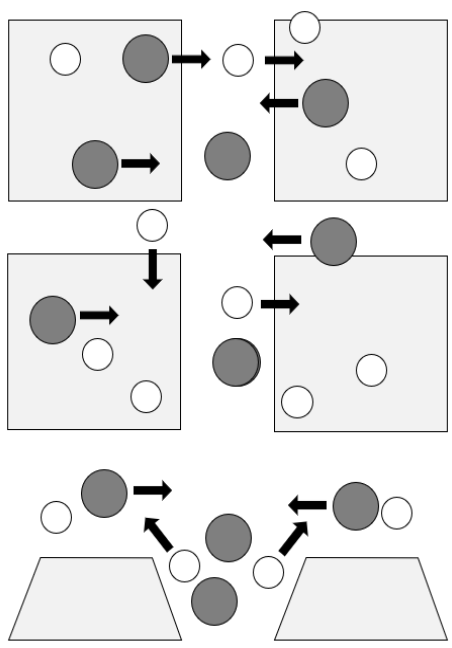

(c)
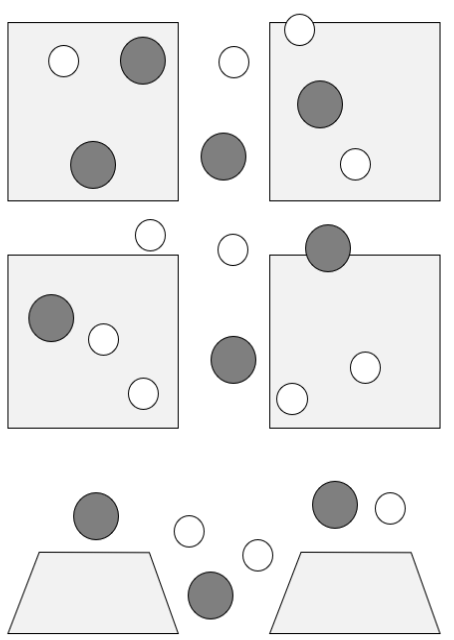

(b)

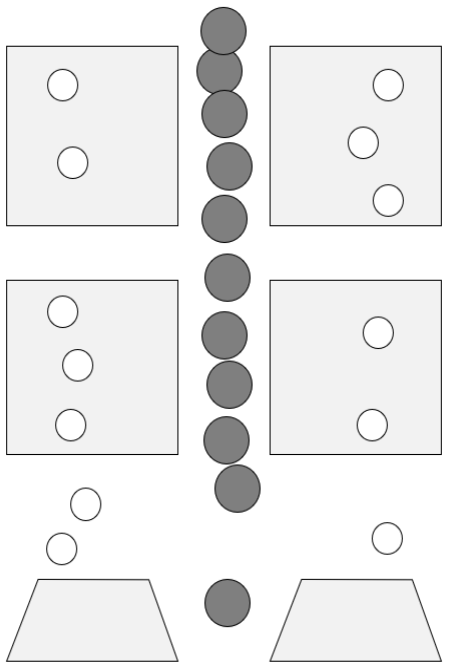

(d)

FIGURE 4. (a) Illustration of DEP tapered microelectrode used to carry out this study, (b) EVs on the microelectrode, (c) direction of EVs' movement, and (d) effect of DEP force on EVs

\section{RESULTS AND DISCUSSION}

In this analytical characterization, as shown in Figure 5, the biological cell which is EVs together with its medium; phosphate-buffered saline (PBS) was used.

Figure 5 explains the attraction force of PDEP to the repulsion force of NDEP. This is explained by the low input frequency values before the crossover frequency value of EVs is exposed to the NDEP repulsive forces. After the crossover frequency values, EVs on high input frequency value is exposed to PDEP attractive forces. The midpoint of transaction forces between PDEP and NDEP is FDEP = 0 . FDEP is zero because the PDEP attractive forces to NDEP repulsive forces are equal. 


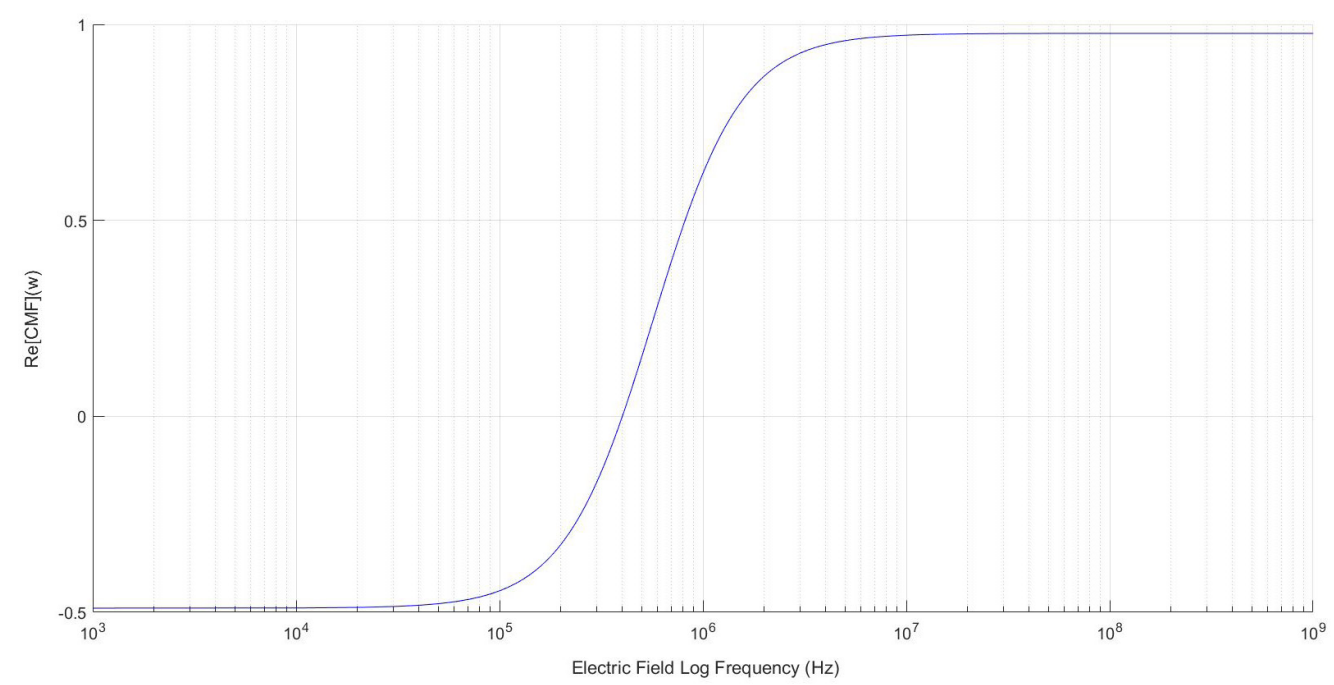

FIGURE 5. The results from the MATLAB analytics software

For this study, well-characterized EVs were recovered from the cell culture media using conventional procedures. Two distinct population of EVs were present in the sample. EVs can be recognized and classified by their size range and protein biomarkers specifically by the origin of the vesicles. TEM was used to verify the size range as mentioned in the methodology and other morphological characteristics. TEM results in Figure 6 show that the EVs are in round-vesicle shaped with the appearance of a single-shell model. The average size of exosomes from the TEM from ten cell counts is $45 \mathrm{~nm}$. From the figure, it shows that the range of size from TEM falls within the known size range for EVs.

Extracellular vesicles intensity distributions in Figure 6(b) display a bimodal distribution with two peaks approximately at 46 and $283 \mathrm{~nm}$. Gyorgy et al. (2011) also reported the values of exosomes and microvesicles as in agreement with the average values from DLS of this work. The largest population of particles was about 240 $\mathrm{nm}$ in size. The size distribution of EVs was dispersed in the analyzed sample indicating a highly heterogeneous population of EVs.
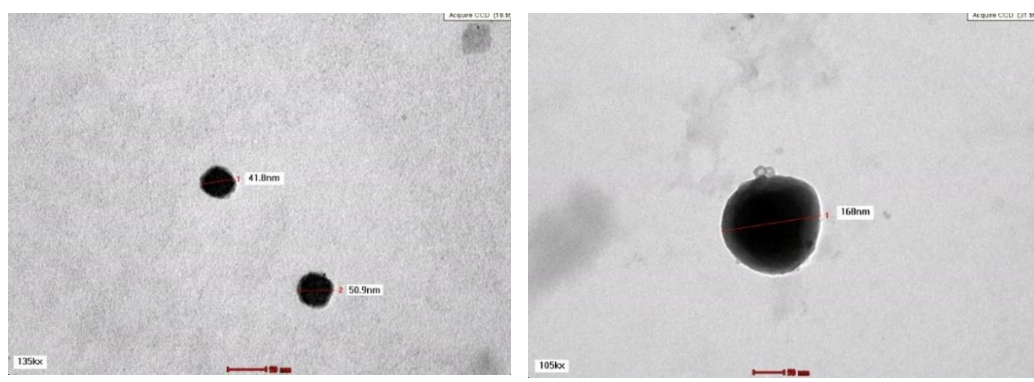

(a)

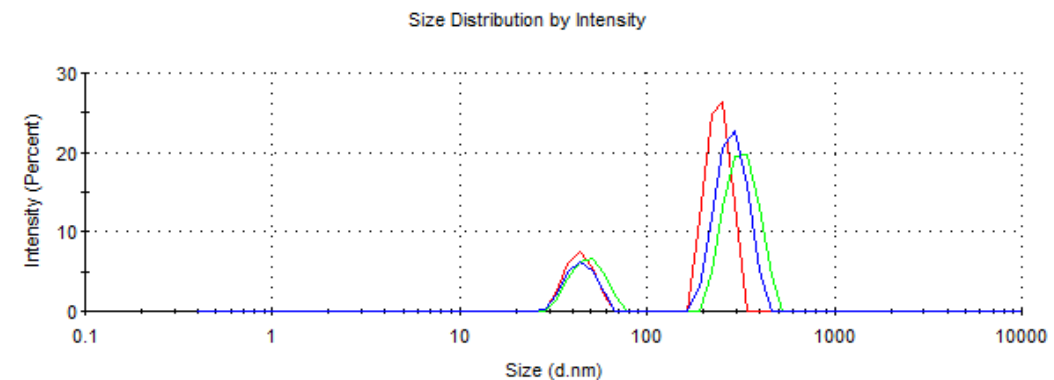

(b)

FIGURE 6. (a) TEM images of EVs that were recovered from cell culture media. The EVs are in a spherical shape with size ranges from $40 \mathrm{~nm}$ to $200 \mathrm{~nm}$, and (b) the two peaks evident the coexistence of large population and the small population of extracellular vesicles 
Due to the complications of viewing the EVs under a normal light microscope, these EVs were fluorescently labeled with the red fluorescent membrane dye, PKH26 before loading onto the DEP microelectrode as shown in Figure 7(a). EVs were marked with red PKH26 dye are evident in the sample as red fluorescent coloration and some larger EVs aggregates are visible as red spots.

EVs were first spiked in PBS, and then the sample was loaded onto the DEP microelectrode. A droplet of EVs in which volume $1 \mu \mathrm{L}$ was fixed for each droplet to maintain the volume of EVs on the microelectrode. An AC field was applied to supply the non-uniform electric field for the manipulation of EVs. After the AC field was applied, $20 \mathrm{Vp}$-p at $100 \mathrm{kHz}$, it can be seen the EVs experiencing repulsive forces of FDEP which is NDEP. As discussed previously in Figure 5, at low frequency, the EVs will be exposed to NDEP, thus, shows the same reaction towards the low frequency of $100 \mathrm{kHz}$. In Figure 7(b), there were many EVs scattered off the ROI. This is because the electric field produced by the electrode might differ due to the electrode gap was too large for EVs; this tapered electrode of $80 \mu \mathrm{m}$ of gap usually applied towards large particles which are $1 \mu \mathrm{m}$ and above.

Next, the results in Table 1 show the response of EVs

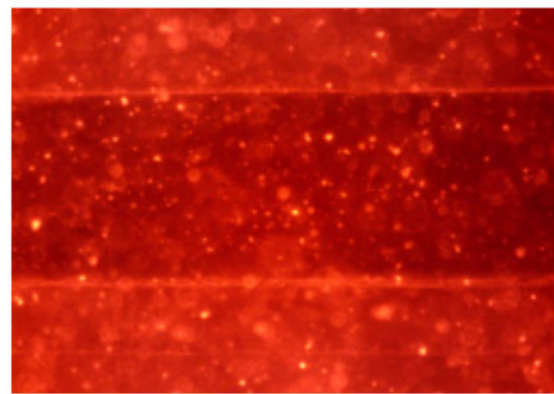

(a)

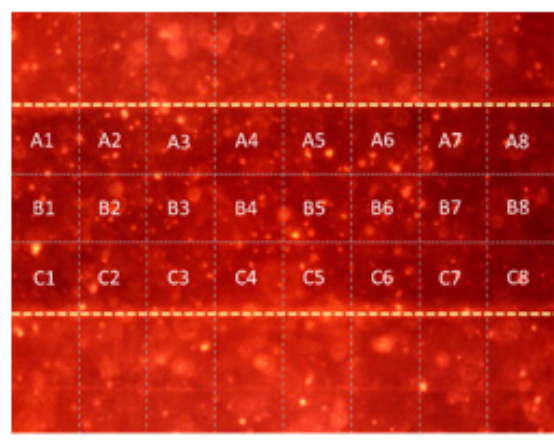

(c)

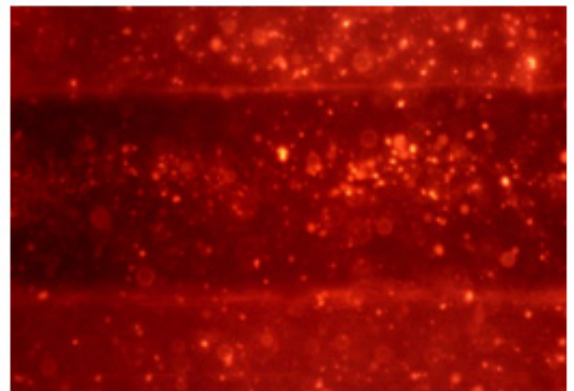

(b)

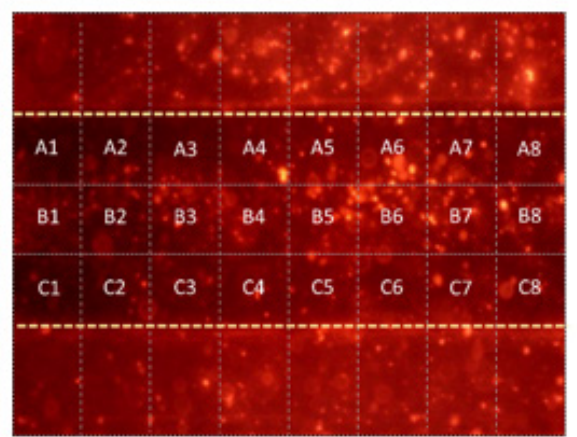

(d)

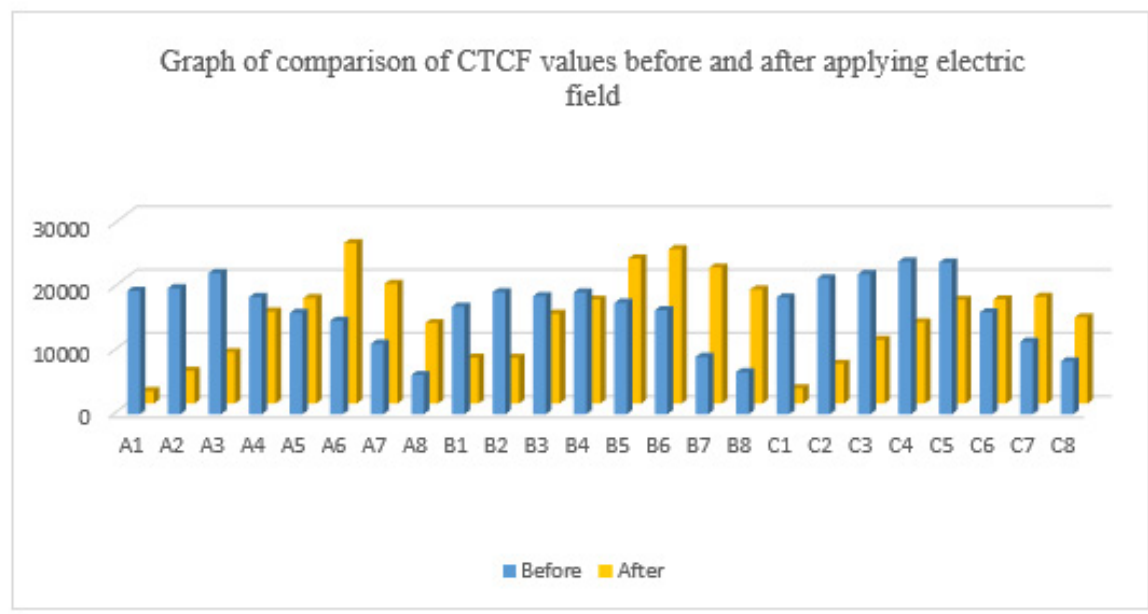

(e)

FIGURE 7. (a) Fluorescence image showing red fluorescent exosomes and EVs labeled with the PKH26 dye dispersed across the chip before the AC field was applied (b) NDEP repulsive force was evident after $60 \mathrm{~s}$ of applying $20 \mathrm{Vpp}$ at $100 \mathrm{kHz}$ (c)(d) The grid analysis for the

ROI (e) Bar graph showing the grid analysis result for before and after applying FDEP 
from $100 \mathrm{kHz}$ to $10 \mathrm{MHz}$. The EVs responded to PDEP and the EVs were repelled to the electrodes from $100 \mathrm{kHz}$ until $400 \mathrm{kHz}$. The EVs were in a uniform state at $450 \mathrm{kHz}$ where there is no mobility in terms of direction, PDEP = NDEP. EVs started to attract at $500 \mathrm{kHz}$ which gives PDEP.

For further analysis of the results stated, the area is divided into three regions with a line parallel to the

TABLE 1. Response of EVs at certain frequencies

\begin{tabular}{ccc}
\hline Frequency value $(\mathrm{kHz})$ & Simulation & Experimental \\
\hline 100 & NDEP & NDEP \\
150 & NDEP & NDEP \\
200 & NDEP & NDEP \\
250 & NDEP & NDEP \\
300 & NDEP & NDEP \\
350 & NDEP & NDEP \\
400 & NDEP & NDEP \\
450 & No movement & No movement \\
500 & PDEP & PDEP \\
600 & PDEP & PDEP \\
700 & PDEP & PDEP \\
800 & PDEP & PDEP \\
900 & PDEP & PDEP \\
1000 & PDEP & PDEP \\
5000 & PDEP & PDEP \\
10000 & PDEP & PDEP \\
\hline
\end{tabular}

electrode and eight regions in an even space distribution perpendicular to the electrode. Each grid is labeled with A to $\mathrm{C}$ for the direction perpendicular to the electrodes and 1 to 8 for direction parallel to the electrodes. The graphic in Figure 7(c) and 7(d) shows the images of the EVs between the electrodes (boundary marked with yellow dotted lines).

Image J is an image analysis software tool used to measure cell Fluorescence. It can determine the level of cellular fluorescence from fluorescence microscopy images. From this software, the method used to determine the fluorescence is using (8):

$\mathrm{CTCF}=$ Integrated Density $-($ Area of selected cell $\times$ Mean fluorescence of background readings)

where CTCF is Corrected Total Cell Fluorescence. This is the value that indicates a more accurate measurement than raw fluorescence data. The area of the selected cell is the cell of interest which we subject with fluorescent staining. The Integrated Density is:
Integrated Density $=$ Area $\times$ Mean fluorescence

The background readings are the dark area between the electrode with no fluorescence. The values of the background readings will provide a more accurate fluorescence value of each selection. Mathematical methods was considered such as the difference in the CTCF sum value near the electrodes compared to the location further from them, and the standard deviation of the CTCF values of any areas between the electrodes before and after applying the electric field.

Using the ImageJ software, the Corrected Total Cell Fluorescence (CTCF) of each grid A1 until C8 is calculated by obtaining the area, and integrated density of each grid cell. Several random selections of areas with no fluorescence between the electrodes are taken as a background. These values are averaged to obtain a more accurate value to use in the formula to calculate CTCF.

According to the graph in Figure $7(\mathrm{e})$, the CTCF highest values before subjecting to the electric field are 
in grid $\mathrm{C} 4, \mathrm{C} 5, \mathrm{~A} 3, \mathrm{C} 3$, and $\mathrm{C} 2$, respectively. After 60 $\mathrm{s}$ of putting the EVs under the electric field, the highest CTCF values now are in grid A6, B6, B5, B7, A7, and B8, respectively. The standard deviation of the CTCF from ' $\mathrm{A}$ ' grid values before applying the electric field is 5277.2.

After applying the electric field, the standard deviation increases to 7654.2. One conclusion that can be made from this calculation is to prove that before applying the electric field, the CTCF values in each ' $\mathrm{A}$ ' grids are closer to mean value across the fixed distance parallel to the electrode on the top side of the picture.

Compared to the standard deviation of the 'A' grids after applying the electric fields, higher values of CTCFs can be observed in the 'A' grids especially A5, A6, and A7. The same observation can be made on the ' $B$ ' grids where the highest CTCF values are all adjacent to A5, A6 and A7.

Across the ' $C$ ' grids, it can be noted that the concentration of CTCF values before applying the electric field is high compared to the values after applying the electrical field. The sum of CTCF values of the ' $\mathrm{C}$ ' grids for before is 145895.7, while the sum of CTCF values after 94892.4, which makes a difference of 51003.3 in CTCF value. For perspective, the average of CTCF values in each grid for before and after applying the electric fields are 16574.9 and 13752.9, respectively. This is consistent with the theory of DEP where the EVs should be repelled away from the electrode if there is an electric field.
' $\mathrm{B}$ ' grids are located the furthest from the electrodes, hence, in theory, the CTCF values should be highest along with these grids. 5 of the 10 highest CTCF values are in the ' $\mathrm{B}$ ' grids - B6, B5, B7, B8, and B4 from highest to lowest. The sum of CTCF values for each 'A', 'B', and 'C' grids before applying electric field are 128143.4, 123759.6, and 145895.7, respectively, while the sum values of each these grids after applying the electric filed are 103396, 131780.3, and 94892.4, respectively. From these values, we can establish that while the numbers before the electric field is applied are random, the sum value of CTCF for after can be interpreted as the concentration of the fluorescence near the electrodes are much lesser ('A' and ' $\mathrm{B}$ ' grids) than in the location where it is further than the electrode ('C' grids), meaning the EVs moved or repelled away from the electrodes.

While the sum difference in CTCF values in 'B' grids does not indicate a significant increase to show the EVs moved in big quantity into this region, it is important to consider that the area under the microscope analyzed in this work is only a fraction of a bigger area. In this case, the microscope is only able to capture the top layer and a part of the device. This could explain the difference in sum CTCF values of before and after the electric field is applied due to the high possibility of the fluorescence moved to adjacent area outside the microscope region. However, it can be observed that the sum CTCF values do decrease significantly along the area close to the electrodes (area 'A' and 'B' grids) (Table 2).

TABLE 2. Summary of sum CTCF values

\begin{tabular}{lccc}
\hline Sum CTCF Values & Region A & Region B & Region C \\
\hline Before & 128143.4 & 123759.6 & 145895.7 \\
After & 103396 & 131780.3 & 94892.36 \\
Difference & 24747.47 & -8020.67 & 51003.31 \\
\hline
\end{tabular}

\section{CONCLUSION}

This study is very crucial for the quantification of EVs released by cells to enhance the development of biomarkers and drug delivery applications. The population and heterogeneity of EVs have been verified by TEM and DLS; which proves the presence of two distinct populations of EVs. Next, the EVs have been successfully labeled using PKH26 dye and thus, provide the ability to view the response of EVs under fluorescent microscope stated in the methodology. This work has demonstrated that this DEP microelectrode technique can perform a simple process to manipulate EVs in less than a minute and has achieved the purpose of having rapid manipulation towards EVs. The grid analysis of the result convinced that this technique is uncomplicated and reliable which provides evidence of EVs manipulation by providing the 
sum of CTCF values. The CTCF values strongly suggest that the manipulation of EVs took place in this study with values of 123759.6 for before and 131780.3 for after applying an electric field in the NDEP arrangement line; the ' $\mathrm{B}$ ' grids in the grid analysis. In addition to that, with only $1 \mu \mathrm{L}$ of the sample, a promising result was present, and this should be considered an extremely useful when manipulating precious samples available in a limited amount.

\section{ACKNOWLEDGEMENTS}

The authors would like to acknowledge with gratitude the sponsor of Dana Cabaran Perdana (DCP-2017-003/3), AKU254: HICOE (FASA2) Artificial Kidney research fund from the Ministry of Higher Education, Malaysia, Geran Galakan Penyelidik Muda (GGPM-2017-028) and Fundamental Research Grant Scheme (FRGS/1/2017/TK04/ UKM/02/14).

\section{REFERENCES}

Admyre, C., Johansson, S.M., Qazi, K.R., Filén, J.J., Lahesmaa, R., Norman, M., Neve, E.P. A., Scheynius, A. \& Gabrielsson, S. 2007. Exosomes with immune modulatory features are present in human breast milk. The Journal of Immunology 179(3): 1969-1978.

Buyong, M.R., Larki, F., Takamura, Y. \& Majlis, B.Y. 2017. Tapered microelectrode array system for dielectrophoretically filtration: Fabrication, characterization, and simulation study. Journal of Micro/Nanolithography, MEMS, and MOEMS 16(4): 44501-44508.

Buyong, M.R., Yunas, J., Hamzah, A.A., Majlis, B.Y., Larki, F. \& Aziz, N.A. 2015. Design, fabrication and characterization of dielectrophoretic microelectrode array for particle capture. Microelectronics International 32(2): 96-102.

Caby, M.P., Lankar, D., Vincendeau-Scherrer, C., Raposo, G. \& Bonnerot, C. 2005. Exosomal-like vesicles are present in human blood plasma. International Immunology 17(7): 879-887.

Clayton, A., Court, J., Navabi, H., Adams, M., Mason, M.D., Hobot, J.A., Newman, G.R. \& Jasani, B. 2001. Analysis of antigen presenting cell derived exosomes, based on immuno-magnetic isolation and flow cytometry. Journal of Immunological Methods 247(1-2): 163-174.

Dixon, C.L., Sheller-Miller, S., Saade, G.R., Fortunato, S.J., Lai, A., Palma, C., Guanzon, D., Salomon, C. \& Menon, R. 2018. Amniotic fluid exosome proteomic profile exhibits unique pathways of term and preterm labor. Endocrinology 159(5): 2229-2240.

Doyle, L.M. \& Wang, M.Z. 2019. Overview of extracellular vesicles, their origin, composition, purpose, and methods for exosome isolation and analysis. Cells 8(7): 727-750.

Edgar, J.R. 2016. Q \& A: What are exosomes, exactly? BMC Biology 14(46): 1-7.

Gascoyne, P.R.C. \& Shim, S. 2014. Isolation of circulating tumor cells by dielectrophoresis. Cancers 6(1): 545-579. doi:10.3390/cancers6010545.
György, B., Szabó, T.G., Pásztói, M., Pál, Z., Misják, P., Aradi, B., László, V., Pállinger, É., Pap, E., Kittel, Á., Nagy, G., Falus, A. \& Buzás, E.I. 2011. Membrane vesicles, current state-of-the-art: Emerging role of extracellular vesicles. Cellular and Molecular Life Sciences 68(16): 2667-2688. doi:10.1007/s00018-011-0689-3.

Haqqani, A.S., Delaney, C.E., Tremblay, T.L., Sodja, C., Sandhu, J.K. \& Stanimirovic, D.B. 2013. Method for isolation and molecular characterization of extracellular microvesicles released from brain endothelial cells. Fluids and Barriers of the CNS 10(1): 4-15.

Jamaludin, N.M.A., Buyong, M.R., Rahim, M.K.A., Hamzah, A.A., Mailis, B.Y. \& Bais, B. 2018. Dielectrophoresis: Characterization of triple-negative breast cancer using clausius-mossotti factor. 2018 IEEE International Conference on Semiconductor Electronics Proceedings (ICSE). pp. 85-88.

Kadaksham, A.T.J., Singh, P. \& Aubry, N. 2004. Dielectrophoresis of nanoparticles. Proceedings of ASME International Mechanical Engineering Congress and Exposition, pp. 85-92.

Muralidharan-Chari, V., Clancy, J., Plou, C., Romao, M., Chavrier, P., Raposo, G. \& D'Souza-Schorey, C. 2009. ARF6-regulated shedding of tumor cell-derived plasma membrane microvesicles. Current Biology 19(22): 18751885.

Pegtel, D.M., Peferoen, L. \& Amor, S. 2014. Extracellular vesicles as modulators of cell-to-cell communication in the healthy and diseased brain. Philosophical Transactions of the Royal Society B 369: 1-9.

Pisitkun, T., Shen, R.F. \& Knepper, M.A. 2004. Identification and proteomic profiling of exosomes in human urine. Proceedings of the National Academy of Sciences of the United States of America 101(36): 13368-13373.

Rahim, M.K.A., Buyong, M.R., Jamaludin, N.M.A., Hamzah, A.A., Siow, K.S. \& Majlis, B.Y. 2018. Characterization of permittivity and conductivity for ESKAPE pathogens detection. IEEE International Conference on Semiconductor Electronics Proceedings (ICSE). pp. 132-135.

Rahman, N.A., Ibrahim, F. \& Yafouz, B. 2017. Dielectrophoresis for biomedical sciences applications: A review. Sensors 17(3): 449-475.

Raposo, G. \& Stoorvogel, W. 2013. Extracellular vesicles: Exosomes, microvesicles, and friends. Journal of Cell Biology 200(4): 373-383.

Sakha, S., Muramatsu, T., Ueda, K. \& Inazawa, J. 2016. Exosomal microRNA miR-1246 induces cell motility and invasion through the regulation of DENND2D in oral squamous cell carcinoma. Scientific Reports 6(December): 1-11. doi:10.1038/srep38750.

Shafiee, H., Jahangir, M., Inci, F., Wang, S., Willenbrecht, R.B.M., Giguel, F.F., Tsibris, A.M.N., Kuritzkes, D.R. \& Demirci, U. 2013. Acute on-chip HIV detection through label-free electrical sensing of viral nano-lysate. Small 9(15): 2553-2563.

Tetta, C., Ghigo, E., Silengo, L., Deregibus, M.C. \& Camussi, G. 2013. Extracellular vesicles as an emerging mechanism of cell-to-cell communication. Endocrine 44(1): 11-19. 
Van Niel, G., D’Angelo, G. \& Raposo, G. 2018. Shedding light on the cell biology of extracellular vesicles. Nature Reviews Molecular Cell Biology 19(4): 213-228.

Vojtech, L., Woo, S., Hughes, S., Levy, C., Ballweber, L., Sauteraud, R.P., Strobl, J., Westerberg, K., Gottardo, R., Tewari, M. \& Hladik, F. 2014. Exosomes in human semen carry a distinctive repertoire of small non-coding RNAs with potential regulatory functions. Nucleic Acids Research 42(11): 7290-7304.

Yunus, F.W., Hamzah, A.A., Norzin, M.S., Buyong, M.R., Yunas, J. \& Majlis, B.Y. 2018. Dielectrophoresis: Iron dificient anemic red blood cells for artificial kidney purposes. IEEE International Conference on Semiconductor Electronics Proceedings (ICSE). pp. 5-8.

Zlotogorski-Hurvitz, A., Dayan, D., Chaushu, G., Korvala, J., Salo, T., Sormunen, R. \& Vered, M. 2015. Human salivaderived exosomes: Comparing methods of isolation. Journal of Histochemistry and Cytochemistry 63(3): 181189.
Nur Mas Ayu Jamaludin, Muhammad Khairulanwar Abdul Rahim, Azrul Azlan Hamzah \& Muhamad Ramdzan Buyong* Institute of Microengineering and Nanotechnology

Universiti Kebangsaan Malaysia

43600 UKM Bangi, Selangor Darul Ehsan

Malaysia

Nadiah Abu

UKM Medical Molecular Biology Institute (UMBI)

UKM Medical Centre

56000 Cheras, Kuala Lumpur, Federal Territory

Malaysia

*Corresponding author; email: muhdramdzan@ukm.edu.my

Received: 4 May 2020

Accepted: 23 June 2020 